\title{
NEW STORMWATER PRIORITY POLLUTANTS: COMPARISON WITH INTERNATIONAL CLASSIFICATIONS, QUALITY CRITERIA AND MONITORING PROGRAMS
}

\author{
Eva Eriksson, \\ Anders Baun, \\ Peter Steen Mikkelsen \\ Anna Ledin \\ Technical University of Denmark, Denmark
}

\begin{abstract}
Stormwater discharges are generated by rain runoff from land and impervious areas such as roads, parking lots, and roofs during rainfall and snowmelt events. It contains an array of different pollutants such as organic matter, particles, heavy metals, inorganic trace elements and xenobiotic organic compounds (XOCs). It is important to consider the hazards concerning these pollutants when considering design of monitoring strategies, comparing different handling strategies for stormwater utilisation, treatment methods and discharge to receiving waters.

In the EU 5FP funded Daywater project a list of selected stormwater priority pollutants (SSPP) was identified, which has been used for assessing pollutant sources and fluxes, behaviour and fate during passage through best management practices (BMPs) and the environmental risk associated with their subsequent dispersal. The methodology used; Chemical Hazard Identification and Assessment Tool (CHIAT) aims at selecting relevant SSPP e.g. and can be used for development and evaluation of monitoring programmes.

The Daywater SSPP-list consists of water quality parameters (BOD, COD, SS, nitrogen, $\mathrm{pH}$ and phosphorus); metals $(\mathrm{Cd}, \mathrm{Cr}, \mathrm{Cu}, \mathrm{Ni}, \mathrm{Pb}, \mathrm{Pt}$ and $\mathrm{Zn}$ ); PAHs (naphthalene, pyrene and benzo[a]pyrene); herbicides (pendimethalin, phenmedipham, glyphosate and terbutylazine); and other XOCs (nonylphenol ethoxylates, pentachlorophenol, di(2-ethylhexyl)phthalate, PCB-28 and MTBE) representing persistent, ubiquitous compounds and compounds deriving from specific anthropogenic sources.

The list was compared with data found within the Danish nation-wide monitoring programmes for the aquatic environment (NOVA2003 and NOVANA); European monitoring programmes; pollutant registers; individual European legislation; as well as quality criteria and limit values. The comparison reveals differences since most of these are set on arbitrary criteria or focuses on the current EU legislation. Overlaps was found with the studied programmes, but also some "new" compounds was selected; platinum, herbicides and MTBE which indicate that revision of existing monitoring programmes is needed and that stormwater contains more hazardous pollutants than previously anticipated.
\end{abstract}




\section{KEYWORDS}

Hazard assessment; Monitoring programme; Stormwater; Xenobiotic compounds

\section{INTRODUCTION}

Stormwater is a vital part of the global water cycle which is receiving increased attention due to climate change[1], as well as the broad spectrum of pollutants such as heavy metals and XOCs (e.g. polycyclic aromatic hydrocarbons (PAH), pesticides, detergents and plasticizers) in quantities that adversely affect the water quality in receiving waters[2,3]. Additionally, application of decentralised systems for treatment, use, and detention of stormwater are increasing both due to altered building procedures resulting in water shortages, and flooding, as well as due to the costs associated with the combined treatment of storm- and wastewater. Both structural and non-structural BMPs (sustainable urban drainage systems; SUDS) are widely used to reduce the urban runoff peak flows as well as the amount of pollutants entering the environment but the re-use of collected stormwater and treatment in BMPs are restricted by the risks related to the handling of water with poor quality. The composition of the stormwater runoff is dependent on the quality of the rainwater and the snow melt events as well as the nature of surfaces (roads, parking lots, roofs etc.) with which it comes into contact during the runoff process. The phase in which the pollutant exists (particulate, colloidal or dissolved) determines how much of the pollutant will be bioaccessable for organisms and what type of treatment is the most feasible option. These stormwater pollutants may cause negative effects to exposed humans, to animals or plants during discharge or use, and may cause technical and aesthetic problems.

In the EU funded Daywater project (EVK1-CT-2002-00111; http://www.daywater.org) a list of selected stormwater priority pollutants (SSPP) was proposed, for use when assessing pollutant sources and fluxes, the behaviour, fate and toxicity of pollutants during passage through BMPs and the environmental risk associated with their subsequent dispersal in the environment[4]. The pollutants on the list are selected to reflect a range of pollutant types, sources and inherent properties when assessing the efficiencies of stormwater pollution management strategies. The objective here was to compare the Daywater SSPP with data found within the Danish nation-wide monitoring programme for the aquatic environment; existing European monitoring programmes; pollutant registers; individual European legislation; as well as quality criteria and limit values.

\section{METHODOLOGY}

The applied methodology, referred to as the Chemical Hazard Identification and Assessment Tool (CHIAT) aims to select the most relevant SSPP using a series of five stages[5,6];

1) Source characterisation,

2) Recipient, receptor and criteria identification,

3) Hazard and problem identification,

4) Hazard assessment and

5) Expert judgement.

CHIAT is inspired by the technical guidance document for risk assessment of chemicals in EU (TGD ${ }^{[7]}$ ) and approaches used in environmental risk assessment of chemicals by governments, chemical industry, environmental organisations, and institutions responsible for 
issuing eco-labels as well as the scientific community, see Figure 1. It was used to determine the SSPP $[4]$ and some of the steps were used in this study.

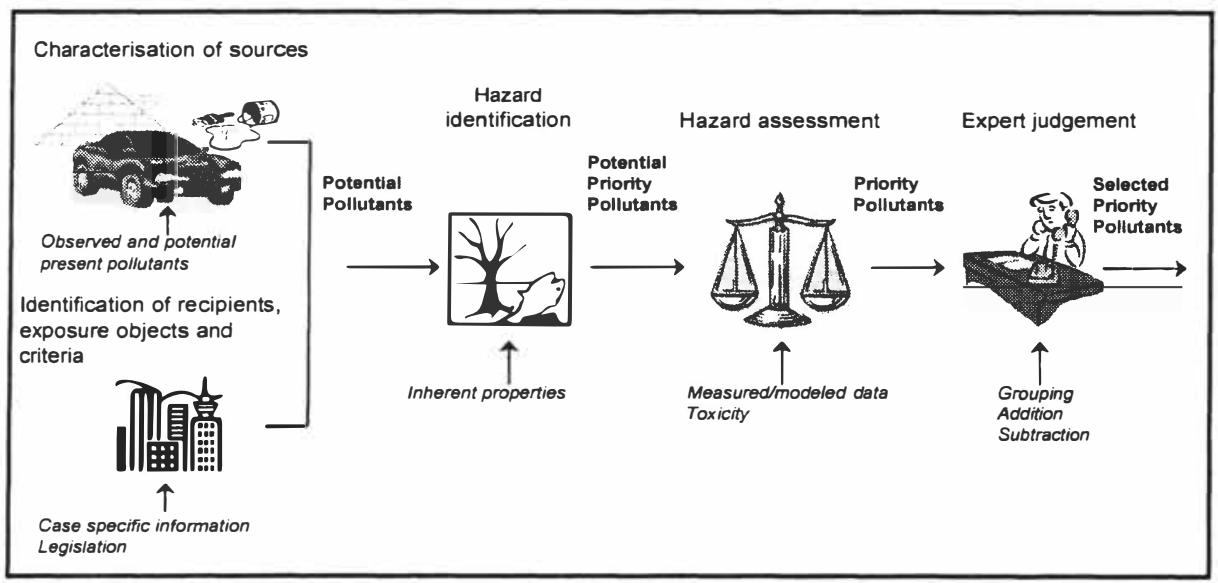

Figure 1. Schematic outline of the 5-step CHIAT procedure.

\subsection{Source characterisation}

In the first step, data concerning the potential chemical pollutant present in stormwater were compiled. A survey focussed on published studies relating to monitored pollutants in order to map what could be deduced from historical monitoring programmes. A different literature survey sought to identify those compounds that may potentially be present in stormwater due to releases from materials, products, traffic etc. or from activities in the urban environment (e.g. for weed control and de-icing), targeting "new" pollutants, which have not yet been included in conventional monitoring programmes. Information on existing European monitoring programmes, including the Danish nation-wide monitoring programme for the aquatic environment, and pollutant registers was collect in this step.

\subsection{Recipient, receptor and criteria identification}

In the second step, the targeted recipients (e.g. water, soil) and exposure objects such as humans, aquatic organisms and crops were identified and criteria and cut-off levels were selected based on the identified recipient and receptors that could be used in the hazard assessment (step 4) as well as legislation that was relevant in the expert judgement (step 5). Common and individual European legislations; as well as quality criteria and limit values were collected. Additionally, recommendations and guidelines from regional nongovernmental interest organizations (here; the North Atlantic and the Baltic Sea) as well as international policy-making authorities were acquired.

\subsection{Hazard and problem identification}

The aim of the hazard and problem identification step was to identify the most important pollutants by ranking them based on their inherent properties, so that the subsequent analysis could focus on these. Step 3, the hazard identification was excluded in this study since this exercise has been performed previous for the SSPP[4]. 


\subsection{Hazard assessment}

Step 4, the hazard assessment consists of a comparison of the exposure and the effects. Here, it was excluded since the major purpose was to compare the SSPP with existing monitoring programmes and legislations i.e. site-specific information regarding environmental concentrations would not be feasible to apply in this selection.

\subsection{Expert judgement}

The fifth and final step involves expert judgement where the "expert" is not a single person but may consist of a group of decision-makers with different educational backgrounds that are required to select priority pollutants for which actions need to be taken in a specific project. The SSPP were selected by partners and core end-users in the Daywater project whereas the decision of which monitoring programmes and legislations etc to compare the SSPP with were made by the authors to this paper.

\section{COMPARISON WITH INTERNATIONAL CLASSIFICATIONS, QUALITY CRITERIA AND MONITORING PROGRAMMES}

Twenty relevant European legislations with lists of priority pollutants and quality criteria and emission standards; recommendations and guidelines from non-governmental organisations on classification of priority pollutants; and nationwide monitoring programmes were found during a survey focusing on relevant governance for stormwater pollutants, see Table 1 . General water quality parameters (BOD, $\mathrm{pH}$, SS etc) were found to only be included in monitoring programmes and not to be classified as priority pollutants. However, the nutrients, nitrogen and phosphorus have this classification due to their potential for causing eutrophication and delayed oxygen consumption.

Cadmium was found to be the only metal included in all statutory orders, guidelines and monitoring programmes, except the ones focussing on organic compounds. It was selected as a SSPP due to a high potential for bioaccumulation, it is highly toxic to aquatic organisms, and causes chronic toxic effects such as cancer and mutations. Chrome and its compounds was the parameter commonly used in all but two studied programmes which focused on chromate $\left(\mathrm{Cr}^{6+}\right)[8,9]$. One focused on total chrome but the quality criteria were also based on chrom-carbonate species [10]. In Daywater, chromate was specifically chosen as it is the dominating chrome specie in the $\mathrm{pH}$ range and composition found in stormwater $[3,11]$. Platinum is not included in any of the legislations or priority pollutants list and it was included as SSPP as a new indicator of specific human sources (platinum-palladium-rhodium car catalysts) that effect the composition of stormwater.

PAHs are in some studied programmes listed as a summary parameter, generally as the 16 EPA summary parameter [12] but not all programmes specified which PAHs that were included. The individual PAH are in focus differentially; benzo[a]pyrene is mentioned individually in 8 of the 20 legislations, lists and monitoring programmes, and included 5 times in a summary parameter. The corresponding numbers for naphthalene are 9 and 6 and for pyrene 3 and 9 . This may be a reflection of the fact that both benzo[a]pyrene and naphthalene are mentioned individually in EU Water framework directive [13]. In the WFD, fluoranthene and not pyrene is selected as indicator for PAHs. In Daywater all 16 EPA PAH was investigated based on sorption and evaporation (Kow and $\mathrm{Kh}$ ) as well as long-term chronic effects. Naphthalene was chosen to represent small, pyrene medium and benzo[a]pyrene large PAHs [4]. 
Table 1. Overview of European and international classification of the Daywater SSPP

\begin{tabular}{|c|c|c|c|c|c|c|c|c|c|c|c|c|c|c|c|c|c|c|c|c|c|}
\hline \multirow[b]{2}{*}{ 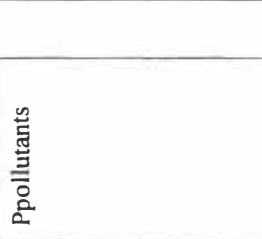 } & \multirow[b]{2}{*}{ 它 } & \multicolumn{10}{|c|}{ Priority pollutants classification } & \multicolumn{7}{|c|}{ Quality criteria and emission standards } & \multicolumn{3}{|c|}{$\begin{array}{l}\text { Monitoring } \\
\text { programmes }\end{array}$} \\
\hline & & 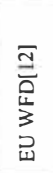 & $\begin{array}{l}\bar{a} \\
\bar{w} \\
\omega \\
2 \\
\text { w }\end{array}$ & 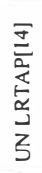 & 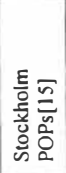 & $\begin{array}{l}3 \\
z \bar{z} \\
\text { 范 } \\
30 \\
30\end{array}$ & 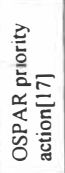 & 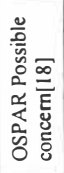 & 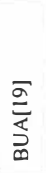 & 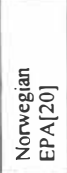 & 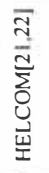 & $\begin{array}{l}\bar{\Xi} \\
\frac{d}{\Delta} \\
\text { 峲 } \\
\frac{5}{5} \\
\frac{5}{5}\end{array}$ & 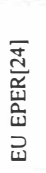 & 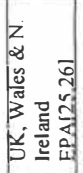 & 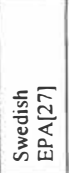 & 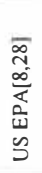 & 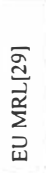 & 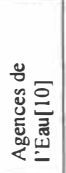 & 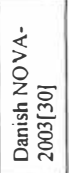 & 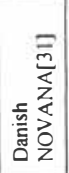 & 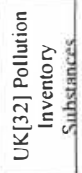 \\
\hline Biological oxygen demand & $\cdot$ & & & & & & & & & & & & & & & & & $\mathrm{X}$ & $\mathrm{X}$ & & \\
\hline Chemical oxygen demand & $\cdot$ & & & & & & & & & & & & & & & & & $\mathrm{X}$ & $\mathrm{X}$ & & \\
\hline Nitrogen & - & & & $\mathrm{X}$ & & & & $\mathrm{X}$ & & & $\mathrm{X}$ & & $\mathrm{X}$ & & $\mathrm{X}$ & & & $\mathrm{X}$ & $\mathrm{X}$ & & $\mathrm{X}$ \\
\hline Phosphorus & $\cdot$ & & & & & & & $\mathrm{X}$ & & & $\mathrm{X}$ & & $\mathrm{X}$ & & $\mathrm{X}$ & & & $\mathrm{X}$ & $\mathrm{X}$ & & $\mathrm{X}$ \\
\hline $\mathrm{pH}$ & $\cdot$ & & & & & & & & & & & & & & & & & $\mathrm{X}$ & $\mathrm{X}$ & & \\
\hline Suspended solids & . & & & & & & & & & & & & & & & & & & $\mathrm{X}$ & & \\
\hline Cadmium & $7440-43-9$ & $\mathrm{x}$ & $\mathrm{X}$ & $\mathrm{X}$ & & & $\mathrm{X}$ & $\mathrm{X}$ & & $\mathrm{X}$ & $\mathrm{x}$ & $\mathrm{x}$ & $\mathrm{X}$ & $\mathrm{x}$ & $\mathrm{X}$ & $\mathrm{X}$ & & $\mathrm{X}$ & $\mathrm{X}$ & $\mathrm{X}$ & $\mathrm{X}$ \\
\hline Chromium (Chromate) & $\begin{array}{l}7440-47-3 \\
(11104-59-9)\end{array}$ & & $\mathrm{x}$ & & & & & & & $x$ & $x$ & $x$ & $x$ & & $x$ & $x$ & & $x$ & $x$ & $x$ & $x$ \\
\hline Copper & $7440-50-8$ & & & & & & & & & $\mathrm{X}$ & $\mathrm{X}$ & $\mathrm{X}$ & $\mathrm{X}$ & & $\mathrm{X}$ & $\mathrm{X}$ & & $\mathrm{X}$ & $\mathrm{X}$ & $\mathrm{X}$ & $\mathrm{X}$ \\
\hline Lead & $7439-92-1$ & $(\mathrm{X})$ & & $\mathrm{X}$ & & & $\mathrm{X}$ & $\mathrm{X}$ & & $\mathrm{X}$ & $\mathrm{X}$ & $\mathrm{X}$ & $\mathrm{X}$ & & $\mathrm{X}$ & $\mathrm{X}$ & & $\mathrm{X}$ & $\mathrm{X}$ & $\mathrm{X}$ & $\mathrm{x}$ \\
\hline Nickel & $7440-02-0$ & $\mathrm{x}$ & $\mathrm{X}$ & & & & & & & & $\mathrm{X}$ & $\mathrm{X}$ & $\mathrm{X}$ & & $\mathrm{X}$ & $\mathrm{X}$ & & $\mathrm{X}$ & $\mathrm{X}$ & $\mathrm{X}$ & $\mathrm{X}$ \\
\hline Platinum & $7440-06-4$ & & & & & & & & & & & & & & & & & & & & \\
\hline Zinc & $7440-66-6$ & & $\mathrm{X}$ & & & & & & & & $\mathrm{X}$ & $\mathrm{X}$ & $\mathrm{X}$ & & $\mathrm{X}$ & $\mathrm{X}$ & & $\mathrm{X}$ & $\mathrm{X}$ & $\mathrm{X}$ & $\mathrm{X}$ \\
\hline Benzo(a)pyrene & $50-32-8$ & $\mathrm{X}$ & & & & $\Sigma$ & $\Sigma$ & $\mathrm{X}$ & & $\Sigma$ & $\Sigma$ & $\mathrm{X}$ & $\Sigma$ & & & $\mathrm{X}$ & & $\mathrm{X}$ & $\mathrm{x}$ & $\mathrm{X}$ & $x$ \\
\hline Naphthalene & $91-20-3$ & (X) & $\mathrm{X}$ & & & $\bar{\Sigma}$ & $\Sigma$ & & $\mathrm{X}$ & $\Sigma$ & $\bar{\Sigma}$ & $\mathrm{x}$ & $\bar{\Sigma}$ & $\mathrm{X}$ & & $\mathrm{X}$ & & $\Sigma$ & $\mathrm{X}$ & $\mathrm{X}$ & $\mathrm{X}$ \\
\hline Pyrene & $129-00-0$ & $\Sigma$ & & & & $\bar{\Sigma}$ & $\bar{\Sigma}$ & & & $\Sigma$ & $\bar{\Sigma}$ & $\Sigma$ & $\bar{\Sigma}$ & & & $\mathrm{X}$ & & $\Sigma$ & $\mathrm{X}$ & $\mathrm{X}$ & $\Sigma$ \\
\hline Glyphosate & $1071-83-6$ & & & & & & & & & & & & & & & & $\mathrm{X}$ & $\mathrm{X}$ & $\mathrm{X}$ & $\mathrm{X}$ & \\
\hline Pendimethalin & $40487-42-1$ & & & & & & & & & & & & & & & & & & $\mathrm{x}$ & $\mathrm{X}$ & \\
\hline Phenmedipham & $13684-63-4$ & & & & & & & & & & & & & & & & & & & & \\
\hline Terbutylazine & $5915-41-3$ & & & & & & & & & & & & & & & & & & $\mathrm{X}$ & $\mathrm{X}$ & \\
\hline Di-(2-ethylhexyl)-phthalate & $117-81-7$ & (X) & $\mathrm{X}$ & & & & $\mathrm{X}$ & $\mathrm{X}$ & $\mathrm{X}$ & $\mathrm{X}$ & & & & & & $\mathrm{X}$ & & & $\mathrm{X}$ & $\mathrm{X}$ & $\mathrm{X}$ \\
\hline MTBE & $1634-04-4$ & & & & & & & & & & & & & & & & & & $\mathrm{X}$ & $\mathrm{X}$ & \\
\hline $\begin{array}{l}\text { Nonylphenol ethoxylates and } \\
\text { degradation products }\end{array}$ & $\begin{array}{l}9016-45-9, \\
25154-52-3,104- \\
40-5\end{array}$ & $\mathrm{x}$ & $\mathrm{x}$ & & & & & & $x$ & $\mathrm{x}$ & $x$ & & & & & $\mathrm{X}^{*}$ & & & $\mathrm{x}$ & $x$ & $x$ \\
\hline PCB 28 & $7012-37-5$ & & & $\Sigma$ & $\Sigma$ & & $\Sigma$ & $\mathrm{x}$ & & $\Sigma$ & $\Sigma$ & $\mathrm{X}$ & & & & $\Sigma$ & & $\Sigma$ & $\mathrm{X}$ & $\mathrm{X}$ & $\Sigma$ \\
\hline Pentachlorophenol & $87-86-5$ & $(X)$ & & & & $\mathrm{x}$ & $x$ & $\mathrm{x}$ & $x$ & $x$ & $\mathrm{x}$ & $\mathrm{x}$ & $x$ & $x$ & & $x$ & & $x$ & $x$ & $x$ & $x$ \\
\hline
\end{tabular}

(X) Undergoing review for priority hazardous substances, $\mathrm{X}^{*}$ under review, $\Sigma$ Summary parameter e.g. PAH or PCB 
None of the herbicides/pesticides included among the SSPP are classified as priority pollutants in any other programme, see Table 1. Their classifications as a SSPP depends not only on their inherent properties which may cause adverse effiects in the environment but also their use and spreading in Europe. Regional and national consumption statistics in the EU was reviewed in order to identify the high volume produced/consumed herbicides. This was compared with studies of pesticide residues in food products in order to find which of the high volume herbicides that are taken up in terrestrial plants [4]. Diuron, which is listed on the WFD, was not selected as SSPP in spite of it's high toxicity to aquatic organisms and widespread use in EU as it's is under discussion for source control (phase-out) and is being substituted by glyphosate in several countries. Glyphosate is regulated in the EU for maximal residual levels in food products and is included in French and Danish monitoring programmes. Pendimethalin and Terbutylazine are both included in the two Danish monitoring programmes as a consequence of the recent discussion in Denmark. Phenmedipham is a new potential and unregulated pollutant.

Nine SSPP were also found on the EU WFD priority substance list [13] which in itself is divided in three levels: priority substances, priority hazardous substances and undergoing review for priority hazardous substances. Among the priority substances are the summary parameter for PAH. The priority hazardous substances are: cadmium and its compounds; benzo[a]pyrene; nickel and its compounds; and nonylphenols. Pentachlorophenol (PCP); di(2-ethylhexyl)-phthalate (DEHP); lead and its compounds; as well as naphthalene are under review for becoming priority hazardous substances.

DEHP is listed as a priority pollutant in the USA [12] and has been included among the SSPP as an indicator of the phthalate group. This group consist of 356 phthalates according to the European chemical Substances Information System (ESIS) and of which 28 are listed as High Production Volume Chemicals (HPVCs) i.e. > 1000 tonnes/year in the EU[33].

In Daywater the nonylphenol ethoxylates and their degradation products were selected as a SSPP. The legislation and lists of priority pollutants contains several different definitions on this theme; ethoxylates, both ethoxylates \& nonylphenol or nonylphenol as well as in the monitoring programmes where specific ethoxylates to monitor are selected (mono- and diethoxylates). It is notable that not all nonylphenol ethoxylate degradation products are in focus; the longer tri- and tetra ethoxylates and the nonylphenol carboxylates are not included in any other programme.

The PCBs are listed as a summary parameter in the legislation and lists of priority pollutants but there are no reference to which compounds that are included in this summary parameter has been found. Thirteen individual PCBs have been analysed in stormwater and one have been confirmed to be over the limit of quantification [3]. The PCB-28 was selected as an indicator of persistent chlorinated compounds with the highest mobility of the PCBs mentioned above, based on water solubility and sorption. It is classified as being of possible concern in the North-Atlantic region [18] and is included in the Danish national monitoring programmes (NOVA-2003 and NOVANA). However, in NOVA-2003 it has not been analysed in stormwater but in industrial wastewater and sewage sludge [30]. Pentachlorophenol is on the list of priority substance in the EU [13]. It has also been suggested by the WWF to become a new persistent organic pollutant (POP) [16]. It is also included in the European Emission Pollutant Register for air emission with a threshold in air of $10 \mathrm{~kg} /$ year for a facility with regulated activities [24], including both point sources and diffuse/non-point sources. 
MTBE is almost exclusively used as a fuel additive in motor petrol intended to reduce harmful tailpipe emissions from motor vehicles. The maximum concentration of MTBE, expressed in Directive 98/70/EC as Ethers containing five or more carbon atoms per molecule is 15 volume percentage [34]. In some countries e.g. Denmark, MTBE is being phased-out in 92- and 95-octane petrol due to aesthetical concerns. MTBE has a strong odour (odour threshold in water is $95 \mu \mathrm{g} / \mathrm{L}$ and taste threshold $134 \mu \mathrm{g} / \mathrm{L}$ [35]) and has due to its high water solubility and low sorption being found in groundwater, the primary drinking water source in Denmark.

Most of the studied programmes only refer to pollutants that have previously been classified as "priority substances", "dangerous substances" and "hazardous substances" but other selection criteria has been used e.g. "long-range transported compounds", " existing substances based on volume consumed or imported" and "persistence to degradation". Additionally, five studied programmes have set the criteria with the focus on environmental or water quality. The Danish national monitoring programmes NOVA-2003 (1998-2003) and NOVANA (2004-2009) aim at pre-mapping quality (chemical, biological and physical) for the implementation of EU water framework directive.

Table 2 Quality criteria for fresh water in $\mu \mathrm{g} / \mathrm{Ls}$ for the Daywater SSPP

\begin{tabular}{|c|c|c|c|c|c|c|c|c|}
\hline Compound & 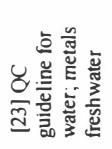 & 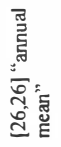 & 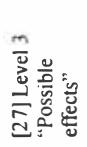 & 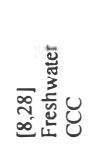 & 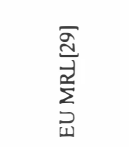 & 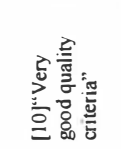 & 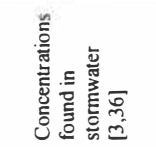 & 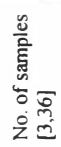 \\
\hline Biological ox ygen demand & & & & & & 3000 & $<1,000-324,000$ & 445 \\
\hline Chemical oxygen demand & & & & & & 20,000 & $\begin{array}{c}1,000 \\
270,000,000\end{array}$ & 1137 \\
\hline Nitrogen & & & 1250 & & & $\Sigma: 3130$ & $180-39,720$ & 475 \\
\hline Phosphorus & & & 50 & & & $\sum 150$ & $<5-26,000$ & 1510 \\
\hline $\mathrm{pH}$ & & & & & & $6 .-8.2$ & $3.81-11.4$ & 1512 \\
\hline Suspended solids & & & & & & & $<100-5,700,000$ & 1294 \\
\hline Cadmium & 5 & 5 & 0.3 & 2.2 & & $0.01-0.09 \#$ & $<0.05-2,000$ & 1219 \\
\hline Chromium (Chromate) & 10 & & 15 & II $(\mathrm{Cr} 6+)$ & & $0.4-3.6 \#$ & $<0.05-4,200$ & 1006 \\
\hline Copper & 12 & & 9 & 9 & & $0.17-2.7 \#$ & $<0.5-6,800$ & 2166 \\
\hline Lead & 3.2 & & 3 & 2.5 & & $2.1-10 \#$ & $<0.5-6,400$ & 2486 \\
\hline Nickel & 160 & & 45 & 52 & & $2.5-12^{*}$ & $<0.02-580$ & 1026 \\
\hline Platinum & & & & & & & $<0.02$ & 5 \\
\hline Zinc & 110 & & 60 & 120 & & $2.3-14 \#$ & $<0.5-25,500$ & 2301 \\
\hline Benzo(a)pyrene & 0.001 & & & $0.0044^{*}$ & & 0.004 & $<0.01-300$ & 222 \\
\hline Naphthalene & 1 & 10 & & $\cdot$ & & totPAH 0.1 & $<0.02-72$ & 799 \\
\hline Pyrene & $\begin{array}{l}\mathrm{PAH}: \\
0.001\end{array}$ & & & $960^{*}$ & & totPAH 0.1 & $<0.02-120$ & 495 \\
\hline Glyphosate & & & & & $\begin{array}{l}0.1-50 \mathrm{mg} / \mathrm{kg} \\
\text { food }\end{array}$ & 0.1 & $<0.1-220$ & 20 \\
\hline \multicolumn{9}{|l|}{ Pendimethalin } \\
\hline \multicolumn{9}{|l|}{ Phenmedipham } \\
\hline Terbutylazine & & & & & & & $<0.05-19.5$ & 21 \\
\hline Di-(2-ethylhexyl)-phthalate & & & & $1.8^{*}$ & & & $3-44$ & 24 \\
\hline MTBE & & & & & & & $0.03-37$ & 612 \\
\hline $\begin{array}{l}\text { Nonylphenol ethoxylates } \\
\text { and degradation products }\end{array}$ & & & & $(5,9)$ & & & $<0.05-23$ & 36 \\
\hline PCB 28 & $\begin{array}{l}\text { IPCB: } \\
0.01\end{array}$ & & & $\begin{array}{l}\text { SPCB } \\
0.014\end{array}$ & & $\Sigma \mathrm{PCB} 0.001$ & $<0.2$ & 3 \\
\hline Pentachlorophenol & 1 & 2 & & 15 & & 0.1 & $<0.4-115$ & 26 \\
\hline
\end{tabular}

$\#$ Three levels of $\mathrm{CaCO} 3:<50 \mathrm{mg} / \mathrm{L} ; 50<\mathrm{CaCO} 3<200$ and $>200 \mathrm{mg} / \mathrm{L}$ 
Quality criteria for the SSPP in fresh water (when available) can be found in Table 2. When comparing with concentrations found in stormwater published in internationally available literature [3] it can be seen that in most cases the maximum concentration found in stormwater vastly exceed the quality criteria. This is of course depending on the quality and number of measured data; for most of the metals $(\mathrm{Cd}, \mathrm{Cr}, \mathrm{Cu}, \mathrm{Pb}, \mathrm{Ni}$ and $\mathrm{Zn}$ ) several large investigations have been made. Pt on the other side has only been investigated in one single study and therefore not be used as a general representative for Pt in stormwater.

It is notable that the for pesticides, although being among the top-20 used pesticides in Europe, only one quality criterion (for Glyphosate) is available and that the number of investigations for pesticides in stormwater from non-agricultural sources is sparse. The observed concentrations of SMTBE do not exceed the odour threshold.

Although the quality criteria in most cases have the same focus; fresh water, there is a variation between the different evaluated programmes. For several metals they are in the same order of magnitude (e.g. $\mathrm{Cu}$ and $\mathrm{Pb}$ ) but great internal variation can be seen e.g. for nickel where the lowest criteria is 2.5 and the highest $160 \mu \mathrm{g} / \mathrm{L}$ deriving from the French river water quality standards and the Danish surface water quality standards, respectively. For pentachlorophenol the quality criteria range from 0.1 to $15 \mu \mathrm{g} / \mathrm{L}$ which is substantially lower than the highest concentration found in stormwater, $115 \mu \mathrm{g} / \mathrm{L}$.

\section{CONCLUSIONS}

Overlaps was found between the evaluated programmes, but also some "new" compounds was selected; platinum, herbicides (pendimethalin, phenmedipham and terbutylazine) and MTBE which indicate that revision of existing monitoring programmes may be needed and that stormwater contains more hazardous pollutants than previously anticipated.

Stormwater can be heavily polluted with respect to the SSPP, substantially exceeding the quality criteria, and treatment before discharge may therefore be required. The evaluated programmes were found to contain quality criteria for several of the SSPP but great variation in concentration values between the different programmes could be seen.

\section{ACKNOWLEDGEMENTS}

The results presented in this publication have been obtained within the framework of the EC funded research project Daywater "Adaptive Decision Support System for Stormwater Pollution Control", contract no EVK1-CT-2002-00111 which is organised within the "Energy, Environment and Sustainable Development" Programme in the 5th FP for "Science Research and Technological Development" of the European Commission and is part of the CityNet Cluster, the network of European research projects on integrated urban water management. The authors would also acknowledge the Technical University of Denmark, the Swedish Urban Water Management Programme and the Danish Environmental Protection Agency for partial funding.

\section{REFERENCES}

[1] Grum, M., Jørgensen, A.T., Johansen, R.M., Linde, J.J., 2005. The effect of climate change on urban drainage: An evaluation based on regional climate simulations. In: Eriksson E., Genç-Fuhrman H., Vollertsen J., Ledin A., Hvitved-Jacobsen T. and Mikkelsen P.S. (Eds) 10th International Conference on Urban Drainage, 21-26 August 2005, Copenhagen/Denmark, Draft papers, CD-ROM. 
[2] Makepeace, D.K., Smith, D.W., Stanley, S.J., 1995. Urban stormwater quality: summary of contaminant data. Critical Reviews in Environmental Science and Technology 25, 93139.

[3] Eriksson, E., 2002. Potential and problems related to reuse of water in households. Ph.D. thesis. Institute of Environment \& Resources, Technical University of Denmark.

[4] Eriksson, E., Baun, A., Mikkelsen, P.S., Ledin, A., 2005a. Selection of stormwater priority pollutants. In: Eriksson, E., Genc-Fuhrman, H., Vollertsen, J., Ledin, A., Hvitved-Jacobsen, T. \& Mikkelsen, P. S. (eds.): 10th International Conference on Urban Drainage, 21-26 August 2005, Copenhagen/Denmark, 10ICUD, Draft Papers. CDROM, Institute of Environment \& Resources, Technical University of Denmark \& Section of Environmental Engineering, Aalborg University, Kgs. Lyngby, Denmark.

[5] Eriksson, E., Baun, A., Mikkelsen, P.S., Ledin, A., 2005b. Chemical hazard identification and assessment tool for evaluation of stormwater priority pollutants. Water Science and Technology 51(2),47-55.

[6] Ledin, A., Eriksson, E., Baun, A., Aabling, T., Mikkelsen P.S., 2005. CHIAT Chemical hazard identification and assessment tool - A methodology for chemical risk assessment of different strategies for handling of storm- and wastewater. VA-Forsk, Svenskt Vatten AB, Stockholm. VA-Forsk rapport, 2005-09. (in Swedish).

[7] European Commission, 2003. Technical Guidance Document in support of Commission Directive 93/67/EEC on Risk Assessment for new notified substances, Commission Regulation (EC) No 1488/94 on Risk Assessment for existing substances and Directive 98/8/EC of the European Parliament and of the Council concerning the placing of biocidal products on the market. 2nd version.

[8] US EPA, 2005. Water quality criteria. Available on: http:/oaspub.epa.gov/wqsdatabase/wqsi_epa_criteria.rep_parameter (2005-09-15).

[9] European Chemicals Bureau, 2005. The Priority Lists Existing Substances Regulation (ESR). Available on: http://ecb.jrc.it/existing-chemicals/ (2005-06-14).

[10] Agences de l'Eau, 2000. River Water Quality Assessment System (Système D'évaluation de la qualité de l'eau des cours d'eau. S.E.Q. Eau (version 1) Principles Generaux. (in French).

[11] Parkhurst D.L., Appelo C. A. J., 2001. PHREEQC. Downloaded from http://water.usgs.gov/software/phreeqc.html (Oct. 2001).

[12] US EPA, 2005. Polycyclic aromatic hydrocarbons -- 16-PAH. Available on: http://iaspub.epa.gov/srs/srs_proc_qry.navigate?P_SUB_ID=17134016 (2005-10-10).

[13] European Commission, 2000. Establishing the list of priority substances in the field of water policy and amending Directive 2000/60/EC. Available on: http://europa.eu.int/eur-lex/pri/en/oj/dat/2001/1_331/1_33120011215en00010005.pdf (2005-08-29).

[14] United Nations, 1998. United Nations Economic Commission for Europe (UNECE) Convention on Long-Range Transboundary (LRTAP). Available on: http://www.unece.org/env/lrtap/status/lrtap_s.htm (2005-08-29).

[15] Stockholm POPs, 2005. Information available on: http://www.pops.int/ (2005-06-15).

[16] WWF, 2005. Stockholm Convention New POPs: Screening Additional POPs Candidates. Available on: http://www.worldwildilfe.org/toxics (2005-06-15).

[17] OSPAR, 2004. OSPAR List of Chemicals for Priority Action, OSPAR convention for the protection of the marine environment of the North-east Atlantic meeting of the OSPAR Commission (OSPAR) Reykjavik: 28 Junes- 1 July 2004, 2004-12, A7, § 7.3.

[18] OSPAR, 2002. OSPAR List of Substances of Possible Concern, 2002-17. Available on: http://www.ospar.org 
[19] Advisory Committee on Existing Chemicals (BUA), 2005. BUA reports. Available on: http://www.gdch.de/taetigkeiten/bua/berichte_e.htm (2005-10-03) (in German).

[20] Norwegian Pollution Control Authority, 2005. State of the Environment Norway, List of Priority Substance. http://www.environment.no/templates/pagewide

Available 3280.aspx (2005-10-03).

[21] HELCOM, 1998. HELCOM recommendation 19/5, HELCOM objective with regard to hazardous substances, 26 March 1998. Available on: www.helcom.fi (2005-10-03).

[22] HELCOM, 2005. HELCOM guidelines for the fourth Baltic Sea pollution load compilation (PLC-4) (www.helcom.fi; 2005-10-03).

[23] Danish Ministry of Environment and Energy, 1996. Statutory Order No. 921 of 8 October 1996 on quality standards for water bodies and emission standards for discharges of certain hazardous substances to watercourses, lakes or the sea. (in Danish).

[24] European Commission, 2000. 2000/479/EC: Commission Decision of 17 July 2000 on the implementation of a European pollutant emission register (EPER) according to Article 15 of Council Directive 96/61/EC concerning integrated pollution prevention and control (IPPC). Available on: http://europa.eu.int/comm/environment/ippc/eper/ (2005-10-03).

[25] UK and Welsh EPA, 1998. Statutory Instrument 1998 No. 389 The Surface Waters (Dangerous Substances) (Classification) Regulations 1998. Available on: http://www.opsi.gov.uk/si/sil 998/19980389.htm (2005-06-15).

[26] Northern Ireland Department of the Environment, 1998. Statutory Rule 1998 No. 397. Surface Waters (Dangerous Substances) (Classification) Regulations (Northern Ireland) 1998. Available on: http://www.opsi.gov.uk/sr/sr 1998/19980397.htm (2005-06-15).

[27] Swedish EPA, 1999. Bedömningsgrunder för miljökvalitet. Sjöar och vattendrag. Rapport 4913. (in Swedish).

[28] US EPA, 2005. Water quality criteria for nonylphenol. Available on: http://www.epa.gov/waterscience/criteria/nonylphenol/draftfs.htm (2005-09-15).

[29] European Commission, 2005. Maximum Residue Levels (MRLs); EU MRL Informal coordination of MRLs established in Directives 76/895/EEC, 86/362/EEC, 86/363/EEC, and 90/642/EEC. Available on: http://europa.eu.int/comm/food/plant/protection/resources/mrl_pesticide.pdf

[30] Danish EPA, 2000. NOVA-2003, Programbeskrivelse for det nationale program for overvågning af vandmiljøet i Danmark, 1998-2003. Redegørelse nr. 1 2000. (in Danish).

[31] Danish EPA, 2005. Laboratorier udpeget til analyser for miljøfremmede stoffer og tungmetaller under NOVANA revision. MILJØstyrelsen Vandenheden 1. maj 2005, J.nr. 2040-0008, SR/KIS/Vandenheden. (in Danish).

[32] UK-EPA, 2005. Pollution Inventory Substances. Available on: http://www.environmentagency.gov.uk/business/444255/446867/255244/?version=1\&lang=_e (2005-09-15).

[33] ECB, 2005. ESIS: European chemical Substances Information System, version 4.00. Available on http://ecb.jrc.it/existing-chemicals/ (2005-08-29).

[34] European Commission, 1998. Directive 98/70/EC of the European Parliament and of the Council of 13 October 1998 relating to the quality of petrol and diesel fuels and amending Council Directive 93/12/EEC.

[35] European Fuel Oxygenates Association (EFOA), 2005. ECETOC/EFOA Risk Assessment Report for Existing Substances. Available on: http://www.efoa.org (March 2005).

[36] Kayhanian, M., Singh, A., Suverkropp, C., Borroum S., 2003. Impact of annual average daily traffic on highway runoff pollutant concentrations. Journal of Environmental Engineering 129(11), 975-990. 